\title{
Aspek Individu Balita Dengan Kejadian ISPA Di Kelurahan Cibabat Cimahi
}

\section{Individual Aspect Of Toddler With Ari Occurrence In Cibabat Cimahi Village}

\author{
Ade Saputra Nasution
}

\begin{abstract}
ABSTRAK
Latar Belakang: Penyumbang angka morbiditas dan mortalitas yang tinggi pada balita salah satunya adalah Infeksi saluran pernapasan akut (ISPA), Penyakit ISPA yang diderita oleh balita banyak terjadi di Negara berkembang seperti Indonesia, dimana setiap tahun angka kejadiannya selalu tinggi. Penyakit ISPA pada balita sampai saat ini masih menjadi masalah kesehatan yang mendapatkan perhatian khusus karena tingginya angka kejadian ISPA di Indonesia yang menyebabkan mortalitas. Adapun penyabab kejadian ISPA pada balita ada tiga faktor yaitu faktor individu (umur, status imunisasi, jenis kelamin, berat badan lahir, asi eksklusif dan status gizi), faktor lingkungan fisik (jenis dinding, suhu, kelembapan dan kepadatan hunian, bahan bakar untuk memasak) dan faktor perilaku merokok anggota keluarga di dalam rumah.

Tujuan: Penelitian ini memiliki tujuan untuk menganalisis hubungan aspek individu dengan risiko kejadian ISPA pada balita.

Metode: Penelitian ini menggunakan pendekatan Cross Sectional dengan analisis menggunakan Chi Square Hasil penelitian ini adalah ada untuk melihat faktor penyebab ISPA pada aspek individu (jenis kelamin, asi eksklusif, status imunisasi berat badan lahir, status gizi)

Hasil: analisis risiko aspek balita pada faktor umur, jenis kelamin, imunisasi, asi eksklusif dan status gizi ada hubungan dengan kejadian ISPA, sedangkan berat badan lahir rendah tidak ada hubungan dengan kejadian ISPA

Kesimpulan : Dari hasil penelitian ini bisa direkomendasikan kepada orang tua yang mempunyai balita untuk memperhatikan faktor individu seperti kelengkapan status imunisasi harus dipenuhi, asi eksklusif sampai 6 bulan karena merupakan salah satu pencegah ispa paling mudah dilakukan oleh orang tua, bahkan pencegahan ispa pada balita bisa dilakukan masih di dalam kandungan untuk pemenuhan gizi ibu supaya menghindari BBLR pada anak yang akan dilahirkan.
\end{abstract}

Kata kunci: aspek individu balita, ispa

\section{ABSTRACT}

Background: Acute Respiratory Infection (ARI) is one of the contributors to the high morbidity and mortality in infants, which is suffered by toddlers in many developing countries such as Indonesia, where every year, the incidence is always high. ARI in toddlers is still a health problem that receives special attention because of the high incidence of ARI in Indonesia, which causes mortality. As for the causes of ARI incidence in toddlers there are three factors namely individual factors (age, immunization status, sex, birth weight, exclusive breast milk and nutritional status), physical environmental factors (wall type, temperature, humidity, and occupancy density, cooking fuel ) and smoking behavior factors of family members in the house.

Objective: This study aims to analyze the relationship between individual aspects with the risk of ARI in toddlers.

Methods: This study uses a cross-sectional approach with analysis using Chi-Square. The results of this study are there to look at the factors causing ARI in the individual aspects (sex, exclusive breastfeeding, birth weight immunization status, nutritional status)

Results: aspects of toddlers on age, sex, immunization, exclusive breastfeeding, and nutritional status have a relationship with the incidence of $A R I$, whereas low birth weight has no relationship with the incidence of $A R I$

Conclusion : it's suggested to pay attention to individual factors such as completeness of immunization status must be fulfilled, exclusive breastfeeding up to 6 months because it is one of the most natural preventions of ARI done by parents, even prevention of $A R I$ in toddlers can be done still at in the womb for the fulfillment of maternal nutrition in order to avoid LBW in children who will be born.

Keywords: an individual aspect of the toddler, ARI, nutrition

*Korespondensi:

Ade Saputra Nasution

adenasutioners@gmail.com

Kesehatan Masyarakat Universitas Ibn Khaldun Bogor, Jawa Barat, Indonesia 


\section{PENDAHULUAN}

Mortalitas dan morbiditas di Indonesia dan negara berkembang masih merupakan masalah kesehatan yang cukup besar, khususnya angka mortalitas bayi dan balita masih cukup tinggi. Pada masa bayi dan balita daya tahan atau antibody masih dalam keadaan yang belum cukup kuat, sehingga dapat menimbulkan risiko terjadinya penyakit atau infeksi sangat tinggi. ${ }^{1}$ Berdasarkan SDKI tahun 2018 angka mortalitas bayi di Indonesia sebesar 24 / 1.000 kelahiran hidup, sedangkan angka mortalitas balita 32 / 1.000 kelahiran hidup. Infeksi Saluran Pernafasan Akut (ISPA) merupakan salah satu penyakit yang menyumbang prevalensi morbiditas yang tinggi pada balita. 2.3 .4

ISPA adalah suatu kondisi yang menyerang sebagian dari masyarakat dalam waktu tertentu dan merupakan salah satu masalah kesehatan utama penyebab mortalitas balita dan bayi di Indonesia. ${ }^{5}$ Penyebab morbiditas dan mortalitas bayi dan Balita yang tinggi masih didominasi oleh ISPA. ISPA dapat menyerang jaringan alveoli yang berada di paru-paru dan mempunyai gejala seperti batuk, sesak napas, dan ISPA dikategorikan penyakit infeksi akut. Bronkhus yang mengalami infeksi akut bersamaan dengan proses terjadinya ISPA yang disebut bronchopneumonia. ISPA sering dikaitkan dengan kegagalan fungsi organ seperti terjadinya edema paru, hipoksemia arteri, dan ekskresi karbon dioksida terganggu. ISPA merupakan salah satu penyakit pembunuh nomor satu pada balita di dunia, jika dibandingkan dengan masalah kesehatan lain seperti Malaria, Campak dan AIDS. ISPA sering disebut sebagai The Forgotten Pandemic atau pandemi yang terlupakan. ${ }^{6.7 .8}$

ISPA pada balita dapat disebabkan oleh faktor agent yaitu bakteri dan virus, faktor lingkungan (ventilasi, pencemaran udara yang berada dalam rumah, status sosial ekonomi dan kepadatan hunian), faktor perilaku dan faktor individu balita itu sendiri (imunisasi, umur anak, berat badan lahir, jenis kelamin, status gizi dan vitamin A). ${ }^{9.5}$ Hasil penelitian lain menyatakan ada faktor pendidikan dan pengetahuan ibu, suplementasi, crowding, durasi pemberian ASI, pendapatan keluarga, pajanan rokok, serta perilaku dan sikap ibu terhadap penyakit ISPA. ${ }^{10}$

Salah satu faktor penyebab terjadinya ISPA pada balita seperti kurangnya konsumsi makanan atau tidak terpenuhinya asupan zat gizi yang seimbang dan bergizi akan menyebakan permasalahan pada kondisi tubuh.
Permasalahan intake makanan pada balita akan menyebabkan pertumbuhan terhambat, menurunnya berat badan, turunnya daya tahan tubuh dan kerusakan mukosa yang dapat mengalami perubahan dari sistem pernapasan pada sirkulasi paru juga disertai turunnya kekebalan seluler sehingga memudahkan balita terserang ISPA. ${ }^{11}$

Penelitian ini bertujuan untuk mengidentifikasi penyebab ISPA pada balita yang dilihat aspek individu balita itu sendiri (umur anak, berat badan lahir, imunisasi, jenis kelamin dan status gizi). Dimana aspek individu itu sendiri juga sangat mempengaruhi terjadinya ISPA pada balita seperti hasil penelitian terdahulu. Hasil penelitian Sukmawati dan Sri ada hubungan kejadian ISPA dengan status gizi balita di Puskesmas Tunikamaseang. Begitu juga hasil penelitian yang dilakukan Astuti dkk memperoleh hasil yang signifikan antara kejadian ISPA yang disebabkan oleh status gizi. ${ }^{12.13}$

\section{METODE}

Penelitian ini menggunakan pendekan cross sectional dengan sampel berjumlah 72 balita yang berumur 0 sampai 4.9 tahun, teknik pengambilan sampel yang digunakan adalah teknik random sampling yang dilakukan di Kelurahan Cibabat Cimahi pada mei 2017 dengan menggunakan instrumen yaitu kuesioner dan rekam medik yang hasilnya dianalisis menggunakan uji chi square yang disajikan dalam bentuk tabel dan narasi.

\section{HASIL DAN PEMBAHASAN}

Hasil yang diperoleh dari penelitian ini akan menjabarkan hubungan aspek individu balita dengan terjadinya ISPA yang diderita balita di Kelurahan Cibabat Cimahi.

\section{Hubungan Jenis Kelamin dengan Terjadinya ISPA Balita di Kelurahan Cibabat Cimahi}

Penelitian ini menunjukkan hasil bahwa balita lakilaki sebanyak $62.8 \%$ menderita ISPA, sementara balita berjenis kelamin perempuan yang mengalami ISPA sebanyak $48 \%$. Hasil analisis menunnjukkan bahwa $p$-value $(0,025)<\alpha(0,05)$ artinya ada hubungan terjadinya ISPA yang diderita balita dengan faktor jenis kelamin di kelurahan Cibabat Cimahi.

Tabel 1. Hubungan Jenis Kelamin Dengan Terjadinya ISPA Balita

\begin{tabular}{|c|c|c|c|c|}
\hline \multirow[t]{2}{*}{ Jenis kelamin } & \multicolumn{3}{|c|}{ Kejadian ISPA pada balita } & \multirow[t]{2}{*}{$p$-value } \\
\hline & ISPA & Tidak ISPA & Total & \\
\hline Laki-laki & $22(62.8 \%)$ & 13 (37.1\%) & 35 (100\%) & \multirow{3}{*}{0,025} \\
\hline Perempuan & $18(48.6 \%)$ & $19(51.3 \%)$ & 37 (100\%) & \\
\hline Total & $40(55.5 \%)$ & $32(44.4 \%)$ & $72(100 \%)$ & \\
\hline
\end{tabular}

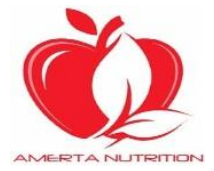

(C)2020. Nasution. Open access under CC BY - SA license.

Received: 16-10-2019, Accepted: 16-03-2020, Published online: 18-06-2020.

doi: 10.20473/amnt. v4i2.2020.103-108 . Joinly Published by IAGIKMI \& Universitas Airlangga 
Hal ini sesuai dengan kondisi balita laki-laki di Kelurahan Babat yang aktifitas diluar rumah lebih tinggi dibandingkan balita perempuan. Dalam kondisi seperti ini jika tidak didukung dengan asupan makanan dengan nutrisi yang seimbang maka balita laki-laki yang aktifitas diluar rumah lebih tinggi bisa menjadi risiko terkena penyakit atau infeksi. Faktor lain yang mempengaruhi mekanisme terjadinya ISPA karena hormonal yaitu hormon $17 \beta$ estradional yang terdapat pada perempuan berfungsi sebagai reaksi imunitas apabila terjadi infeksi. Anak berusia dibawah 5 tahun memiliki kadar IgG yang tidak optimal sehingga dapat menimbulkan risiko ISPA akibat respon imun tidak kuat. ${ }^{14}$ Balita yang aktifitas diluar rumah selain memperhatikan asupan makanan dengan nutrisi yang seimbang, serta menjaga kebersihan diri dengan baik agar balita terhindar dari penyakit atau infeksi. ${ }^{5}$

Hubungan Umur Dengan Terjadinya ISPA Balita di Kelurahan Babat Cimahi

Tabel 2 menunjukkan hasil balita yang berumur 23,9 tahun terjadinya kasus ISPA sebesar $73.6 \%$ dan pada usia 1-1.9 tahun dari 14 balita yang terkena ISPA sebanyak 78.5\%. Hasil analisis chi square menunjukkan p-value $(0,044)<\alpha(0,05)$ artinya ada hubungan umur balita dengan terjadinya ISPA di kelurahan Cibabat Cimahi.

ISPA balita adalah kejadian infeksi pertama yang diakibatkan belum optimalnya kekebalan tubuh secara alamiah. Sistem kekebalan yang ada di dalam tubuh seseorang sangat berperan dalam melawan bakteri maupun infeksi virusyang masuk kedalam tubuh seseorang. Dalam keadaan kondisi tubuh yang lemah akan meningkatkan risiko seseorang mengalami infeksi. Kondisi yang seperti ini sering terjadi pada anak - anak dan lansia dikarenakan menurunnya fungsi organ sehingga dapat melemahkan antibody. Sedangkan pada dewasa sudah terjadi kekebalan alamiah yang lebih optima disebabkan dari pengalaman terjadi infeksi sebelumnya. ${ }^{5}$

Pada usia balita memiliki imunitas yang belum optimal maka dari itu perlu sebuah usaha meningkatkan antibodi dengan cara pemberian imunisasi untuk dapat membentuk sistem kekebalan tubuh atau antibodi balita. Pembentukan kekebalan tubuh yang diperoleh dari pemberian imunisasi membutuhkan waktu sehingga dapat berfungsi dengan optimal. Pemberian imunisasi yang lengkap dapat membentuk antibodi yang optimal sehingga dapat mengalahkan perkembangan penyakit di dalam tubuh supaya tidak lebih memburuk jika terserang ISPA. ${ }^{5,7}$

Tabel 2. Hubungan Umur Dengan Terjadinya ISPA Balita

\begin{tabular}{lccc}
\hline \multicolumn{1}{c}{ Umur } & \multicolumn{2}{c}{ Kejadian ISPA pada balita } & Total \\
\cline { 2 - 4 } & ISPA & Tidak ISPA & $4(100 \%)$ \\
\hline $\mathbf{0}$ bulan - $\mathbf{5}$ bulan & $3(75 \%)$ & $1(25 \%)$ & $8(100 \%)$ \\
\hline $\mathbf{6}$ bulan - 11 bulan & $6(75 \%)$ & $2(25 \%)$ & $14(100 \%)$ \\
\hline $\mathbf{1}$ tahun - 1,9 tahun & $11(78.5 \%)$ & $3(21.4 \%)$ & $38(100 \%)$ \\
\hline $\mathbf{2}$ tahun - 3,9 tahun & $28(73.6 \%)$ & $10(26.3 \%)$ & $8(100 \%)$ \\
\hline $\mathbf{4}$ tahun - 4,9 tahun & $6(75 \%)$ & $2(25 \%)$ & $72(100 \%)$ \\
\hline Total & $54(75 \%)$ & $18(25 \%)$ &
\end{tabular}

\section{Hubungan Status Imunisasi Dengan Terjadinya ISPA Balita di Kelurahan Babat Cimahi}

Tabel 3 menunjukkan hasil balita yang memiliki status imunisasinya tidak lengkap sebesar $61 \%$ mengalami ISPA sedangkan balita yang status imunisasinya lengkap tidak mengalami ISPA sebanyak $15.3 \%$. Hasil analisis chi square menunjukkan p-value $(0,047)<\alpha(0,05)$ artinya ada hubungan kejadian ISPA balita dengan status imunisasi di kelurahan Cibabat Cimahi.

Hasil penelitian menggambarkan balita yang memiliki status imunisasinya lengkap tetapi terkena ISPA, hal ini tidak terjadi ketika imunisasi diberikan melainkan terjadinya ISPA setelah beberapa waktu diberikan baru terjadi ISPA. imunisasi merupakan suatu langkah untuk mencegah insiden ISPA pada balita yang merupakan faktor risiko akibat komplikasi dari campak. Jadi, imunisasi seperti difteri dan campak yang diberikan bukan untuk menambah kekebalan tubuh balita secara langsung terhadap serangan kejadian ISPA, melainkan hanya dapat mencegah faktor yang dapat memicu terjadinya ISPA. Walaupun balita telah medapatkan imunisasi lengkap namun insiden ISPA balita masih tinggi yang disebabkan karena belum maksimalnya pemberian vaksin yang dapat secara langsung mencegah terjadinya ISPA seperti imunisasi Campak dan DPT. ${ }^{.15}$

Tabel 3. Hubungan Status Imunisasi dengan Terjadinya ISPA Balita

\begin{tabular}{|c|c|c|c|c|}
\hline \multirow[t]{2}{*}{ Status Imunisasi } & \multicolumn{3}{|c|}{ Kejadian ISPA pada balita } & \multirow[t]{2}{*}{ p-value } \\
\hline & ISPA & Tidak ISPA & Total & \\
\hline Lengkap & $11(84.6 \%)$ & $2(15.3 \%)$ & $13(100 \%)$ & \multirow{3}{*}{0,047} \\
\hline Tidak Lengkap & $36(61 \%)$ & $23(38.9 \%)$ & $59(100 \%)$ & \\
\hline Total & $47(65.2 \%)$ & 25 (34.7\%) & $72(100 \%)$ & \\
\hline
\end{tabular}

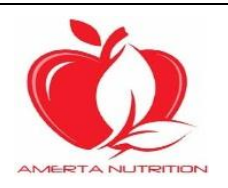

C2020. Nasution. Open access under CC BY - SA license.

Received: 16-10-2019, Accepted: 16-03-2020, Published online: 18-06-2020. doi: 10.20473/amnt. v4i2.2020.103-108 . Joinly Published by IAGIKMI \& Universitas Airlangga 
Balita dengan status imunisasi lengkap bisa juga terkena ISPA, karena daya tahan tubuh anak yang rendah. Kualitas vaksin dan genetik merupakan salah satu upaya tubuh anak untuk dapat menangkal suatu penyakit. Jadi, walaupun balita telah mendapatkan imunisasi lengkap, namun kemungkinan terjadinya ISPA tetap ada. ${ }^{16}$

\section{Hubungan Asi Eksklusif Dengan Terjadinya ISPA Balita di Kelurahan Babat Cimahi}

Tabel 4 menunjukkan hasil balita yang memiliki status ASI Eksklusif mengalami ISPA sebanyak 51.6\%, ini menunjukkan balita yang ASI Eksklusif mengalami ISPA lebih rendah dibandingkan balita yang tidak diberi ASI Eksklusif menderita ISPA sejumlah $58.5 \%$. Hasil analisis chi square menunjukkan $p$-value $(0,029)<\alpha(0,05)$ artinya ada hubungan kejadian ISPA balita dengan status ASI Eksklusif di kelurahan Cibabat Cimahi

Balita dengan status ASI Eksklusif tetapi masih terkena ISPA sejumlah 16 orang atau sebesar $51.6 \%$, hal ini salah satunya disebabkan karena pengetahuan dari orang tua balita yang rendah, asupan makanan yang tidak lengkap dan bergizi seimbang, sehingga daya tahan tubuh anak tidak kuat untuk melawan bakteri maupun virus yang masuk kedalam tubuh. ${ }^{8,17}$

Kandungan dalam ASI sudah sesuai untuk kesehatan bayi dan sudah memenuhi kebutuhan bayi. Dimana didalam ASI memiliki kandungan seperti lemak, protein, kalsium dan gula dengan kadar yang sesuai. ASI juga mimiliki kandungan seperti antibodi, yang berfungsi sebagai pelindung bayi dari perlawanan bibit penyakit selama disusui, dan beberapa waktu setelah itu. Bayi yang selalu mengkonsumsi ASI jarang mengalami terjadinya infeksi saluran pernafasan bagian atas dan salesma pada kelahiran tahun pertama, namun terjadi sebaliknya pada bayi yang tidak diberi ASI. Perkembangan dan pertumbuhan bayi berlangsung secara baik karena ASI. Namun setelah lepas dari ASI maka balita harusnya dibekali dengan asupan makanan yang adekuat sehingga bisa menghasilkan daya tahan tubuh yang baik dan meminimalkan terjadinya risiko penyakit maupun infeksi. ${ }^{17}$

Tabel 4. Hubungan ASI Eksklusif dengan Terjadinya ISPA Balita

\begin{tabular}{lcccc}
\hline \multicolumn{1}{c}{ Status Imunisasi } & \multicolumn{3}{c}{ Kejadian ISPA pada balita } & p-value \\
\cline { 2 - 4 } Eksklusif & ISPA & Tidak ISPA & Total \\
\hline Tidak Eksklusif & $16(51.6 \%)$ & $15(48.3 \%)$ & $31(100 \%)$ & 0,029 \\
\hline Total & $24(58.5 \%)$ & $17(41.4 \%)$ & $41(100 \%)$ & $72(100 \%)$ \\
\hline
\end{tabular}

Hubungan BBLR dengan Terjadinya ISPA Balita di Kelurahan Babat Cimahi

Hasil analisis tabel 5 menggambarkan hasil balita yang memiliki status BBLR mengalami ISPA sebanyak $66.6 \%$, ini menunjukkan balita yang BBLR lebih tinggi mengalami ISPA dibandingkan balita yang normal yang menderita ISPA sebanyak $30.3 \%$, analisis chi square menunjukkan $p$-value $(0,229)>\alpha(0,05)$ yang berarti tidak ada hubungan status BBLR balita dengan insiden ISPA di kelurahan Cibabat Cimahi.

Teori mengemukakan bahwa BBLR merupakan bayi yang lahir kurang < 2500 gram. BBLR dapat mengakibatkan terganggunya pertumbuhan dan maturasi alat - alat dan organ tubuh belum sempurna, daya tahan tubuh terhadap penyakit infeksi sangat lemah, akibatnya BBLR dapat mengalami terjadinya infeksi dan komplikasi yang berakibat fatal pada bayi bahkan bisa menyebabkan mortalitas. ${ }^{12} 5$

Hasil penelitian ini menunjukkan sejalan dari teori, dimana balita yang dilahirkan BBLR lebih banyak mengalami terjadinya ISPA dibandingkan balita yang dilahirkan normal. Ibu hamil yang mengalami gangguang kesehatan dapat menyebabkan gangguan pertumbuhan janin sehingga bayi yang dilahirkan BBLR yang akan mempengaruhi perkembangan fisik, mental dan pertumbuhan masa balita, bahkan lebih fatal dapat meningkatkan risiko kesakitan dan kematian sangat tinggi yang disebabkan oleh adanya gangguan imaturitas organ dan pertumbuhan. Bayi yang dilahirkan dalam kondisi BBLR mengalami gangguan pembentukan antibodi tidak sempurna sehingga lebih rentan terkena infeksi terutama di saluran pernafasan karena masih lemahnya organ pernafasan. $^{5}$

Banyaknya ibu yang bekerja di Kelurahan Cibabat Cimahi yang menitipkan anak balitanya kepada anak tertua atau kepada orang tua mereka, sehingga balita tidak mendapatkan asupan makanan yang seimbang dan bergizi. Kondisi seperti ini terus menerus terjadi sehingga menyebabkan antibody balita sangat lemah dan pertumbuhan dan perkembangan organ terlambat. Disamping itu faktor lingkungan rumah juga mempengaruhi kondisi tersebut, dimana sebagian besar kondisi rumah di wilayah Kelurahan Cibabat Cimahi tidak memenuhi syarat. Ini merupakan salah satu penyebab anak balita yang dilahirkan normal tetapi mengalami terjadinya ISPA.

\section{Hubungan Status Gizi Dengan Terjadian ISPA Balita di Kelurahan Babat Cimahi}

Tabel 6 menunjukkan hasil balita yang menunjukkan status gizi baik mengalami ISPA sejumlah $62.5 \%$ dan balita yang gizi kurang menderita ISPA sebanyak 43.7\%. Hasil analisis chi square menunjukkan p-value $(0,029)<\alpha(0,05)$ artinya ada hubungan status status gizi balita dengan kejadian ISPA di kelurahan Cibabat Cimahi.

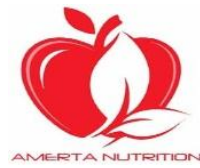

(C)2020. Nasution. Open access under CC BY - SA license.

Received: 16-10-2019, Accepted: 16-03-2020, Published online: 18-06-2020.

doi: 10.20473/amnt. v4i2.2020.103-108 . Joinly Published by IAGIKMI \& Universitas Airlangga 
Tabel 5. Hubungan BBLR dengan Terjadinya ISPA Balita

\begin{tabular}{|c|c|c|c|c|}
\hline \multirow[t]{2}{*}{ BBLR } & \multicolumn{3}{|c|}{ Kejadian ISPA pada balita } & \multirow[t]{2}{*}{ p-value } \\
\hline & ISPA & Tidak ISPA & Total & \\
\hline Normal & $20(30.3 \%)$ & 46 (69.6\%) & 66 (100\%) & \multirow{3}{*}{0,229} \\
\hline BBLR & $4(66.6 \%)$ & $2(33.3 \%)$ & $6(100 \%)$ & \\
\hline Total & $24(33.3 \%)$ & $48(66.6 \%)$ & $72(100 \%)$ & \\
\hline
\end{tabular}

Kekurangan akibat gizi dapat terjadi dari tingkat ringan sampai dengan tingkat berat dan terjadi secara perlahan-lahan dalam waktu yang cukup lama. Balita yang mengalami kurang gizi memiliki risiko terkena penyakit bahkan bisa menyebabkan mortalitas. Teori mengemukakan faktor yang dapat menyebabkan terjadinya ISPA bagi balita yaitu status gizi, dimana keadaan balita yang mengalami status gizi kurang dapat memperlambat pertumbuhan dan perkembangan hormonal pada balita sehingga bisa menyebabkan terjadinya infeksi bahkan bisa menyebabkan mortalitas. ${ }^{18}$

Asupan makanan akan menghasilkan zat gizi memiliki efek yang kuat untuk reaksi resistensi terhadap infeksi dan imunitas tubuh. Balita yang dalam keadaan kurang energi protein, sehingga menyebabkan tmenurunnya ketahanan tubuh dan virulensi patogen lebih kuat dapat menyebabkan mudah terserang infeksi dan terganggunya keseimbangan tubuh, untuk mempertahankan kondisi tubuh dalam keadaan seimbang diperlukan asupan gizi yang cukup dan seimbang untuk memenuhi status gizi yang baik. Protein dikatakan sebagai sumber zat gizi utama yang dibutuhkan tubuh dan sebagai salah satu untuk pembentukan enzim yang berfungsi dalam metabolisme tubuh, termasuk sistem imun. Antibodi globulin gamma yang disebut dengan istilah imunoglobilin merupakan $20 \%$ dari seluruh energi plasma. Immunoglobulin terdiri dari rantai polipeptida yang mengandung berbagai jenis asam amino spesifik. Salah satu asam amino yang berfungsi dalam sistem imun yaitu asam amino treonin yang memiliki kemampuan dapat mencegah masuknya bakteri dan virus terutama paru-paru dan saluran nafas. Sistem imun yang tidak baik bisa dipengaruhi oleh kekurangan protein di dalam tubuh sehingga dapat menyebabkan tubuh lebih mudah terpapar penyakit infeksi. Selain itu, kekurangan protein juga dapat berdampak terhadap metabolisme vitamin dan mineral dimana berfungsi sebagai anti oksidan yang tidak mampu berfungsi secara maksimal, dalam kondisi ini mengakibatkan baik flora normal maupun bakteri dari luar dapat dengan mudah berkembang dan meningkatnya virulensi, sehingga dapat menyebabkan timbulnya gejala penyakit, termasuk ISPA. ${ }^{13.4}$

Tabel 6. Hubungan Status Gizi dengan Terjadinya ISPA Balita

\begin{tabular}{|c|c|c|c|c|}
\hline \multirow[t]{2}{*}{ Status Gizi } & \multicolumn{3}{|c|}{ Kejadian ISPA pada balita } & \multirow[t]{2}{*}{ p-value } \\
\hline & ISPA & Tidak ISPA & Total & \\
\hline Gizi Baik & $5(62.5 \%)$ & $3(37.5 \%)$ & $8(100 \%)$ & \multirow{3}{*}{0,029} \\
\hline Gizi Kurang & $28(43.7 \%)$ & $36(56.2 \%)$ & $64(100 \%)$ & \\
\hline Total & $33(45.8 \%)$ & 39 (54.1\%) & $72(100 \%)$ & \\
\hline
\end{tabular}

Namun hasil penelitian ini juga menunjukkan balita yang status gizi baik mengalami ISPA, hal ini dikarenakan oleh adanya faktor lain menyebabkan terjadinya ISPA balita yaitu sosial ekonomi, kepadatan hunian, polusi udara, asap rokok maupun faktor lingkungan rumah yang tidak memenuhi syarat. ${ }^{19,20}$ Kondisi rumah di Kelurahan Cibabat Cimahi Utara banyak tidak memenuhi syarat seperti kamar yang dihuni lebih dari 2 orang, tidak memiliki ventilasi dan perilaku merokok anggota keluarga di dalam rumah.

\section{KESIMPULAN}

Ada hubungan antara kejadian ispa pada balita dipengaruhi oleh faktor individu (ASI Eksklusif, status gizi, umur, status imunisasi, jenis kelamin), namun status BBLR mendapatkan hasil yang berbeda yaitu tidak berhubungan dengan kejadian ISPA pada balita.

\section{ACKNOWLEDGEMENT}

Penulis mengucapkan terimakasih kepada mahasiswa yang membantu dalam pengumpulan data dan teman dosen atas masukan, pendapat maupun saran dalam perancangan dan penyelesaian penulisan artikel ini.

\section{REFERENSI}

1. Maitatorum, E. \& Zulaekah, S. Status Gizi, Asupan Protein, Asupan Seng Dan Kejadian ISPA Anak Balita Di Perkampungan Kumuh Kota Surakarta. J. Kesehat. 1, 21-30 (2011).

2. Schuetz, P. et al. Procalcitonin to Guide Initiation and Duration of Antibiotic Treatment in Acute Respiratory Infections: An Individual Patient Data MetaAnalysis. Major Artic. 55, 651-62 (2012).

3. Nair, H. et al. Global And Regional Burden Of Hospital

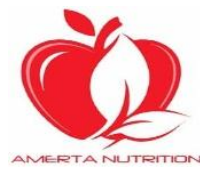

C2020. Nasution. Open access under CC BY - SA license.

Received: 16-10-2019, Accepted: 16-03-2020, Published online: 18-06-2020.

doi: 10.20473/amnt. v4i2.2020.103-108 . Joinly Published by IAGIKMI \& Universitas Airlangga 
Admissions For Severe Acute Lower Respiratory Infections In Young Children In 2010: A Systematic Analysis. Lancet 381, 1380-90 (2013).

4. Nurwijayanti. Keterkaitan Kekurangan Energi Protein (KEP) Dengan Kejadian Infeksi Saluran Pernafasan Akut (ISPA) Pada Balita Usia (1-5 Tahun). J. Care 4, (2016).

5. Fibrila, F. Hubungan Usia Anak, Jenis Kelamin Dan Berat Badan Lahir Anak Dengan Kejadian ISPA. J. Kesehat. Metro Sai Wawai 8, (2015).

6. Burkhardt, 0 . et al. Procalcitonin guidance and reduction of antibiotic use in acute respiratory tract infection. Eur. Respir. J. 36, 601-607 (2010).

7. Matthay, M. A., Ware, L. B. \& Zimmerman, G. A. The Acute Respiratory Distress Syndrome. J Clin Invest 122, 2731-2740 (2012).

8. Sugihartono, N. Analisis Faktor Risiko Kejadian Pneumonia Pada Balita di Wilayah Kerja Puskesmas Sidorejo Kota Pagar Alam. J. Kesehat. Lingkung. Indones. 11, (2016).

9. Trisnawati, Y. \& Khasanah, K. Analisis Faktor Instrinsik Dan Ekstrinsik Yang Berpengaruh Terhadap Infeksi Saluran Pernapasan Akut (ISPA) Pada Balita. J. Kebidanan 5, (2013).

10. Nasution, K. et al. Infeksi Saluran Nafas Akut Pada Balita Di Daerah Urban Jakarta. Sari Pediatr. 11, (2009).

11. Hayati, S. Gambaran Factor Penyebab Infeksi Saluran Pernafasan Akut (ISPA) Pada Balita Di Puskesmas Pasirkaliki Kota Bandung. J. IImu Keperawatan 2, (2014).

12. Ayu, S. dan S. D. Hubungan Status Gizi, Berat Badan Lahir, Imunisasi Dengan Kejadian ISPA Pada Wilayah Kerja Puskesmas Tunikamaseang Kabupaten Maros. Media Gizi Pangan 10, 16-20 (2010).

13. Astuti, A. B., Rahayu, S. \& Surasmi, A. Status Gizi Balita Dengan Kejadian Ispa Pada Anak Balita. J.
Terpadu IImu Kesehat. 1, 1-132 (2012).

14. Ranantha, R., Mahawati, E. \& S, K. K. Hubungan Antara Karakteristik Balita Dengan Kejadian ISPA Pada Balita Di Desa Gandon Kecamatan Kaloran Kabupaten Temanggung. (Artikel Ilmiah. Fakultas Kesehatan. Universitas Dian Nuswantoro Semarang, 2012).

15. Rachmawati, D. A. Faktor Resiko Yang Berhubungan Dengan Kejadian Pneumonia Pada Balita Umur 12-48 Bulan Di Wilayah Kerja Puskesmas Mijen Kota Semarang. J. Kesehat. Masy. 2, (2013).

16. Sambominanga, P. S., Ismanto, A. Y. \& Onibala, F. Hubungan Pemberian Imunisasi Dasar Lengkap Dengan Kejadian Penyakit Ispa Berulang Pada Balita Di Puskesmas Ranotana Weru Kota Manado. J. Keperawatan 2, (2014).

17. Choyron, V. A. G. Hubungan Pemberian ASI Eksklusif Dengan Kejadian Pneumonia Pada Balita Di Wilayah Kerja Puskesmas Peda Kalten. (Artikel Penelitian. Program Studi Kesehata Masyarakat. Fakultas IImu Kesehatan. Universitas Muhammadiyah Surakarta, 2015).

18. Hadiana, S. Y. M. Hubungan Status Gizi Terhadap Terjadinya Infeksi Saluran Pernapasan Akut (ISPA) Pada Balita Di Puskesmas Pajang Surakarta. (Naskah Publikasi. Fakultas Kedokteran. Universitas Muhammadiyah Surakarta, 2013).

19. Halim, Y. \& Pambudi, W. Hubungan Status Gizi Dengan Prevalensi ISPA Pada Anak Usia 6-24 Bulan Di Puskesmas Wilayah Kota Administratif Jakarta Barat Periode Januari-April 2017. Tarumanagara Med. J. 1, 428-433 (2019).

20. Sukmawati \& Ayu, S. D. Hubungan Status Gizi, Berat Badan Lahir (BBL), Imunisasi Dengan Kejadian Infeksi Saluran Pernafasan Akut (ISPA) Pada Balita Di Wilayah Kerja Puskesmas Tunikamaseang Kabupaten Maros. Media Gizi Pangan 10, 16-21 (2010). 